
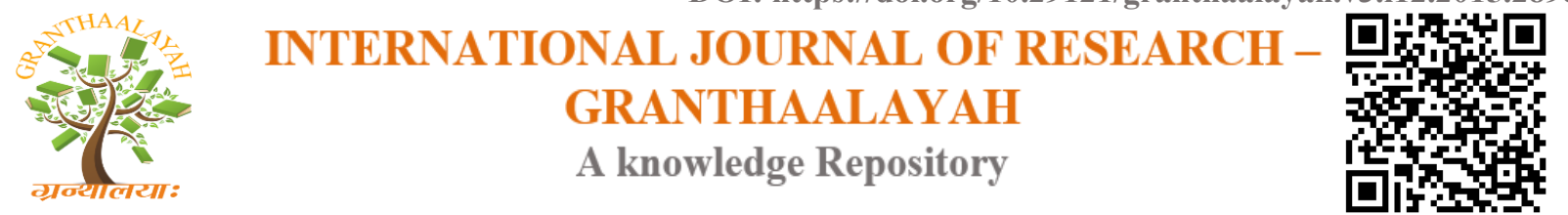

Management

\title{
GST IN INDIA: A KEY TAX REFORM
}

\author{
Monika Sehrawat ${ }^{* 1}$, Upasana Dhanda ${ }^{* 2}$ \\ ${ }^{* 1,}{ }^{* 2}$ M.com, NET -JRF, Delhi University, INDIA
}

\begin{abstract}
GST is one of the most crucial tax reforms in India which has been long pending. It was supposed to be implemented from April 2010, but due to political issues and conflicting interests of various stakeholders it is still pending. It is a comprehensive tax system that will subsume all indirect taxes of states and central governments and unified economy into a seamless national market. It is expected to iron out wrinkles of existing indirect tax system and play a vital role in growth of India. This paper presents an overview of GST concept, explains its features along with its timeline of implementation in India. The paper is more focused on advantages of GST and challenges faced by India in execution.
\end{abstract}

Keywords:

Tax, Indirect tax, Goods and Service Tax (GST), India.

Cite This Article: Monika Sehrawat, and Upasana Dhanda, "GST IN INDIA: A KEY TAX REFORM" International Journal of Research - Granthaalayah, Vol. 3, No. 12(2015): 133-141.

\section{INTRODUCTION}

The proposed GST is likely to change the whole scenario of current indirect tax system. It is considered as biggest tax reform since 1947. Currently, in India complicated indirect tax system is followed with imbrications of taxes imposed by union and states separately. GST will unify all the indirect taxes under an umbrella and will create a smooth national market. Experts say that GST will help the economy to grow in more efficient manner by improving the tax collection as it will disrupt all the tax barriers between states and integrate country via single tax rate. GST was first introduced by France in 1954 and now it is followed by 140 countries. Most of the countries followed unified GST while some countries like Brazil, Canada follow a dual GST system where tax is imposed by central and state both. In India also dual system of GST is proposed including CGST and SGST.

\section{LITERATURE REVIEW}

Agogo Mawuli (May 2014) ${ }^{1}$ studied, "Goods and Service Tax-An Appraisal" and found that GST is not good for low-income countries and does not provide broad based growth to poor 
countries. If still these countries want to implement GST then the rate of GST should be less than $10 \%$ for growth.

Dr. R. Vasanthagopal $(2011)^{2}$ studied, "GST in India: A Big Leap in the Indirect Taxation System" and concluded that switching to seamless GST from current complicated indirect tax system in India will be a positive step in booming Indian economy. Success of GST will lead to its acceptance by more than 130 countries in world and a new preferred form of indirect tax system in Asia also.

Ehtisham Ahmed and Satya Poddar (2009) $)^{3}$ studied, "Goods and Service Tax Reforms and Intergovernmental Consideration in India" and found that GST introduction will provide simplier and transparent tax system with increase in output and productivity of economy in India. But the benefits of GST are critically dependent on rational design of GST.

Nitin Kumar (2014) ${ }^{6}$ studied, "Goods and Service Tax- A Way Forward" and concluded that implementation of GST in India help in removing economic distortion by current indirect tax system and expected to encourage unbiased tax structure which is indifferent to geographical locations.

Pinki, Supriya Kamma and Richa Verma (July 2014) ${ }^{7}$ studied, "Goods and Service Tax- Panacea For Indirect Tax System in India" and concluded that the new NDA government in India is positive towards implementation of GST and it is beneficial for central government, state government and as well as for consumers in long run if its implementation is backed by strong IT infrastructure.

\section{OBJECTIVE OF STUDY}

The study has following objectives:

1) To cognize the concept of GST

2) To study the features of GST

3) To evaluate the advantages and challenges of GST

4) To furnish information for further research work on GST.

\section{RESEARCH METHODOLGY}

Being an explanatory research it is based on secondary data of journals, articles, newspapers and magazines. Considering the objectives of study descriptive type research design is adopted to have more accuracy and rigorous analysis of research study. The accessible secondary data is intensively used for research study.

\section{CONCEPT}

GST is an indirect tax which will subsume almost all the indirect taxes of central government and states governments into a unified tax. As the name suggests it will be levied on both goods and services at all the stages of value addition. It has dual model including central goods and service tax (CGST) and states goods and service tax (SGST). CGST will subsume central 
indirect taxes like central excise duty, central sales tax, service tax, special additional duty on customs, counter veiling duties whereas indirect taxes of state governments like state vat, purchase tax, luxury tax, octroi, tax on lottery and gambling will be replaced by SGST. Integrated goods and service tax (IGST) also called interstate goods and service tax is also a component of GST. It is not an additional tax but it is a system to examine the interstate transactions of goods and services and to further assure that the tax should be received by the importer state as GST is a destination based tax.

\section{TIMELINE OF GST IN INDIA}

In 2000, an empowered committee was set up by NDA government under the chairmanship of Asim Das Gupta to design GST model. With UPA in power union finance minister, Mr. P.Chidambaram, proclaimed the implementation of GST from April2010 in budget of 2007and set up an empowered committee of state Finance ministers to work with center. Therefore, on 10 May 2007 Joint Working Group was set up by empowered committee of state finance ministers which submitted the report in Nov 2007.First detailed discussion paper on structure of GST was introduced by empowered committee in Nov 2009 with the objective of generating a debate and getting the inputs from all stakeholders. It suggested a dual GST Module along with a GST council and finally in March 2011, constitution $115^{\text {th }}$ amendment bill was introduced to draw up laws for implementing GST. It includes the followings:

1) Setting up of GST COUNCIL by the president within 60 days of passage of bill. The council will chaired by union finance minister and its members includes MoS for revenue and finance ministers of states. It will work on GST rates, exemption limits etc.

2) Setting up of a GST Dispute Settlement Authority having three members to resolve dispute arising among states and take action against states.

3) GST Amendment Bill was referred to parliamentary committee on finance for evaluation.

In Aug 2013 the standing committee submitted the report and recommended that proposed Dispute Settlement Authority should be removed and its mechanism should be given to GST Council itself. It also recommended that GST Council should take decision by voting rather than consensus. The representation in the GST Council should be 1/3 from central and rest 2/3 from states. The decision in the council should be passed with more than $3 / 4$ vote representatives present. The quorum of council is raised from proposed $1 / 3$ to half by standing committee.

But the proposed 115 amendment bill was lapsed with dissolution of $15^{\text {th }}$ Lok Sabha.

On 19 Dec 2014 after making slight changes in GST Bill, NDA government redefined it in $16^{\text {th }}$ Lok Sabha as $122^{\text {nd }}$ amendment of constitution. On 6 may 2015 it passed in lower house of government.

Currently, the $122^{\text {nd }}$ constitutional amendment is cragfasted in Rajya Sabha where it has to passed with $2 / 3^{\text {rd }}$ majority in order to be implemented from 1April 2016. 


\section{FEATURES OF PROPOSED GST}

\section{AMBIT OF GST}

1) It is applied to all taxable goods and services except the exempted goods and services and on transactions below the threshold limit.

2) Exempted goods and services include alcohol for human consumption, electricity, custom duty, real estate.[Proposed article 366(12A)]

3) Petroleum products [crude oil, HSD(high speed diesel),motor spirit( petrol), natural gas, ATF(aviation turbine fuel)] are initially exempted from GST till the GST Council announces date of their inclusion.

4) Tabaco products are included in GST along with central excise tax.

\section{IMPOSITION AND COLLECTION OF GST}

1) The power of making law on taxation of goods and services lies with both union and state legislative assemblies. A law made by union on GST will not overrule a state GST law.(proposed article 246A)

2) GST has two components CGST and SGST as discussed above. CGST will be collected by central government whereas states governments will collect SGST.

3) IGST is levied on supplies in the course of interstate trade incuding imports which is collected by central government exclusively and distributed to imported states as GST is destination based tax. The proportion of distribution between center and states is decided on recommendation of GST Council.(proposed article 269A)

\section{GST COUNCIL}

1) It is set up by president under article 279-A. It is chaired by union finance minister.

2) It will constitute union minister of state in charge of revenue and minister in charge of finance or taxation or of any other field nominated by state governments. The $2 / 3^{\text {rd }}$ representatives in council are from states and $1 / 3^{\text {rd }}$ from union.

3) The decision of council is made by $3 / 4^{\text {th }}$ majority of the votes cast and quorum of council is $50 \%$.

4) It will make recommendations on

a) Taxes, surcharge, cess of central and states which will be integrated in GST.

b) Goods and services which may be exempted from GST

c) Interstate commerce - IGST- proportion of distribution between state and center

d) Registration threshold limit for GST

e) GST floor rates

f) Special rates during calamities

g) Provision with respect to special category states specially north east states

5) It may also work as Dispute Settlement Authority for GST. 


\section{ADDITIONAL 1\% TAX}

1) Additional $1 \%$ tax on interstate taxable supply of goods which is levied by center and directly portioned to the exporter state (origin state).

2) This tax will be charged for two years or for longer time period recommended by GST Council.

\section{COMPENSATION TO STATES}

1) For maximum of 5 years union will compensate states for the revenue losses arising out of GST implementation.

2) This compensation will be made on the recommendation of GST Council.

\section{ADVANAGES OF GST}

Under GST regime the burden of taxation will be allocated fairly between manufacturing and services via lower tax rates resulting in increased tax base and minimized exemptions. It is anticipated to help in establishing an effective and transparent tax administration. It is expected to remove the cascading effects of taxes and help in establishing of common national market. Apart from this some more advantages of GST are listed below:

\section{IGST- EFFECTIVE LOGISTICS}

In current indirect tax system central sale tax (CST) is paid on interstate commerce of goods. $2 \%$ standard rate of CST is levied and distributed to exporter state as it is origin based tax. The input credit of CST can be offset with CST liabilities only. CST is paid only on interstate commerce of goods and not on supply (transportation) of goods. So, to avoid this tax large corporates build their own godowns in different states and transport their goods among states without paying CST which finally leads to decrease in cost of their product. Because of this tax dodging through warehousing by big corporates growth of small and medium enterprises hampered and they cannot survive in the market.

But, in proposed GST tax regime IGST is levied on interstate commerce and supply (both) of goods and services. Due to this an effective logistics system will come up which will prevent the tax dodging through warehousing by big corporates. This will protect small and medium enterprises from unhealthy competition of big corporates.

\section{ANCILLARIZATION}

In present indirect tax regime all big corporates want to produce each and everything in-house only in order to reduce CST and cascading effect of tax. But in proposed GST system there is no CST and cascading effect which will lead to outsourcing, subcontracting and division of labour. Because of this specialization will increase in future which will help in reducing the cost of production. With the reduced prices domestic goods will be more competitive in international market which will result in increased export and help country to reduce current account deficit. 


\section{SINGLE BASE COMPUTATION}

With the introduction of GST cascading effects of taxes will not exists and there will be a single base for computation of tax for both central government and state government. Initially state governments will lose tax revenue due to less taxable value of goods. But in later years due to availability of cheap goods the number of taxpayers will increase and overall tax collection of states will also boost. This increase in tax revenue will lead to fiscal consolidation which is demanded by current state of Indian economy. As per CRISIL recent report GST is best reckon for fiscal consolidation as there is not much scope to cut government expenditure in India.

\section{EXPORT WILL BE ZERO RATE}

No GST will be levied on exports because of which input credit of exporter will not be affected and he/she can use these input credit in future. With zero rated exports, domestic goods will be more competitive in international market and will help in increasing exports which in turn the fulfillment of objective of 3.5\% share of India in world exports by 2020 .

\section{SIMPLE TAX STRUCTURE}

As multiple indirect taxes of state and central governments on goods and services will be replaced by a single tax, the tax structure will be hoped much simpler and easier to interpretate. Reduction in the accounting complexities for business will make the manufacturing sector more competitive and boost the economy by $1 \%-2 \%$.

\section{CHALLENGES OF GST}

\section{HIGH REVENUE NEUTRAL RATE (RNR)}

RNR is the rate which neutralize revenue effect of state and central government due to change in tax system, means, the rate of GST which will give at least the same level of revenue that is currently earned by state and central governments from indirect taxes is known as RNR. As per 13 finance commission the RNR should be $12 \%$ whereas state empowered committee demanding $26.68 \%$. Union government is reckoning the rate band should be $15 \%-20 \%$ which is very high as compare to other counties. Hungary implemented GST from 1/4/2014 with $7 \%$ rate. Due to high RNR

- Competitive edge of India in Asian giants will decrease and domestic industry may be wrecking.

- Tax evasion and smuggling will increase.

- Regressive nature of indirect taxes will badly affect the purchasing power of poor people which will have negative impact on human development index.

So, before implementing GST, RNR should be minimized. This can be achieved by inclusion of petrol, liquor, land, electricity within the ambit of GST which will enhance the tax base and increase revenue of government. 


\section{COMPENSATION TO STATES}

Currently, VAT is highest contributor in tax revenue of state governments. But after GST reform this will subsumed along with surcharge and cess into GST. Due to which state governments will occur revenue loss for sure and they will be more dependent on finance commission for tax devolution (currently 42\%). To neutralize their revenue losses states are demanding compensation from union government. As per 14 finance commission union has to compensate states for maximum of five years with tapering effects. For first three years $100 \%$ compensation reduced to $75 \%$ and $50 \%$ in fourth and fifth year respectively. This compensation by union will lead to fiscal burden and may not fulfill the fiscal deficit target of 3\% by March 2017 announced by finance minister in 2015 budget. This fiscal target must be achieved for faster economy growth and full capital account convertibility in future.

Industrialized states will be at loss in GST regime due to its destination based feature. It will demotivate the manufacturing industry and incite states to import more in order to increase their tax revenue. It is not good for manufacturing industry as well as for India because boosted manufacturing sector is the main driver of our economic growth in future. For temporarily relief to industrialized states additional $1 \%$ tax for two years on interstate sale and supply of goods is proposed in GST. Bit with $1 \%$ additional tax, the main objective of GST to minimize cascading effect of taxes is fading out. So, to minimize cascading effect this additional tax at least should not be levied on supply of interstate goods.

\section{REGISTRATION THRESHOLD LIMIT}

At present there are different threshold limits for VAT (5 lacs), service tax ( 10 lacs) and excise duty (1.5 crore). But for implementation of GST common threshold limit for all indirect taxes is required. It will turn into a conflict between state and center. States want to fix the limit as 10 lacs opposing 25 lacs limit suggested by union. The lower threshold limit will broaden the tax base and increase the revenue of government but it will also require a dandy IT infrastructure, to address the database of increased assess, which is presently missing out in Indian states. IT infrastructure will play a vital role in implementing IGST as union will electronically distribute IGST to states. To grapple the data base a strong network is required which is managed by GSTN(Goods and Service Tax Network) proposed in GST. GSTN has major responsibility to tackle biggest challenge of IT infrastructure in a time bound manner.

\section{OTHER ISSUES}

- Union government need to coordinate with 30 states for "input credit" due to transfer of credit in SGST.

- State tax officials training and development before implementation of GST.

- Effective credit mechanism is essential for GST. Owing to CENVAT it is not a problem but for states again it is a major challenge.

- Analysts say that real estate market will be cramped by GST and it may result in $12 \%$ down turn in demanded of new houses because of increased cost up to $8 \%$. (A study commissioned by Curtin university of technology) 


\section{WAY FORWARD FOR IMPLEMENTATION OF GST}

1) The $122^{\text {nd }}$ amendment bill to be passed by upper house with $2 / 3^{\text {rd }}$ majority and then will be ratified by at least $50 \%$ state legislatures and will be followed by assent of president.

2) After the bill has been passed, GSTC (GST Council) to be established.

3) GSTC to advocate GST law and procedure.

4) GST law to be introduced in parliament.

5) GSTN (GST Network) a section- 25 company established to design IT infrastructure of GST

\section{CONCLUSION}

Due to dissilient environment of Indian economy, it is demand of time to implement GST. Consumption and productions of goods and services is undoubtedly increasing and because of multiplicity of taxes in current tax regime administration complexities and compliance cost is also accelerating. Thus, a simplify, user -friendly and transparent tax system is required which can be fulfilled by implementation of GST. Its implementation stands for a coherent tax system which will colligate most of current indirect taxes and in long term it will lead to higher output, more employment opportunities and flourish GDP by 1-1.5\%. It can also be used as an effective tool for fiscal policy management if implemented successfully due to nation-wide same tax rate. It execution will also results in lower cost of doing business that will make the domestic products more competitive in local and international market. No doubt that GST will give India a world class tax system by grabbing different treatment to manufacturing and service sector. But all this will be subject to its rational design and timely implementation. There are various challenges in way of GST implementation as discussed above in paper. They need more analytical research to resolve the battling interest of various stake holders and accomplish the commitment for a cardinal reform of tax structure in India.

\section{REFRENCES}

[1] Agogo Mawuli (2014): "Goods and Service Tax-An Appraisal"Paper presented at the the PNG Taxation Research and Review Symposium, Holiday Inn, Port Moresby,29-30.

[2] Dr. R. Vasanthagopal (2011), "GST in India: A Big Leap in the Indirect Taxation System”, International Journal of Trade, Economics and Finance, Vol. 2, No. 2, April 2011.

[3] Ehtisham Ahamad and Satya Poddar(2009), "Goods and Service Tax Reforms and Intergovernmental Consideration in India", "Asia Research Center”, LSE, 2009.

[4] Girish Garg, (2014), "Basic Concepts and Features of Good and Service Tax in India".

[5] https://en.wikipedia.org/wiki/Goods_and_Services_Tax_(India)_Bill

[6] Nitin Kumar (2014), "Goods and Service Tax in India-A Way Forward", "Global Journal of Multidisciplinary Studies”, Vol 3, Issue6, May 2014.

[7] Pinki, Supriya Kamna, Richa Verma(2014), "Good and Service Tax - Panacea For Indirect Tax System In India”, "Tactful Management Research Journal”, Vol2, Issue 10, July2014

[8] www.gstindia.com/basics-of-gst-implementation-in-indial

[9] wwww.prsindia.org/billtrack/the-constitution-122nd-amendment-gst-bill-2014-3505/ 
[10] wwww.taxguru.in/goods-and-service-tax/goods-service-tax-gst-2.html

[11] wwww.thehindu.com/bussiness/industry/ten-things-to-know-about-gstbill/article7137615.ece

[12] www.top10wala.in/facts-about-gst-india-advantages/ 